\title{
Non-destructive simple model to estimate the leaf area through midvein in cultivars of Vitis vinifera
}

\author{
Amanda Heemann Junges ${ }^{1} \&$ Rafael Anzanello ${ }^{2}$
}

\begin{abstract}
Mathematical models are indirect and non-destructive methods for estimating the leaf area (LA), an important parameter associated with canopy vigor in Vitis vinifera vineyards. This work aims to adjust and test mathematical models for estimating LA using the midvein length of the Vitis vinifera cultivars conducted in horizontal and vertical training systems in the Serra Gaúcha region, Brazil. Leaves were collected in 'Chardonnay', 'Cabernet Sauvignon' vineyards conducted in trellis and lyre training systems, and in 'Merlot' vineyards conducted in trellis and espalier systems. Models were tested for establishing the correlations among the parameters LA and midvein length, considering the cultivar/training system and the general data set. For validation, linear regression between the observed and estimated LA was defined. The relationship between the midvein length and LA was defined by non-linear potential equations $\left(\mathrm{R}^{2}{ }_{\mathrm{aj}} 0.95-0.98\right)$. The performances of the specific and general models were similar regardless of the cultivar/training system. The adjusted models showed excellent results in the validation step (correlation 0.950.98; Wilmott index $>0.97$ and confidence index $>0.92$ ). It is possible to estimate the LA of Vitis vinifera Chardonnay, Cabernet Sauvignon, and Merlot cultivars using a simple non-destructive model that employs one single measurement of the leaf blade, to optimize the vegetative canopy quantification in vineyards.
\end{abstract}

Index terms: 'Chardonnay', 'Cabernet Sauvignon', 'Merlot', Serra Gaúcha.

\section{Modelo simples e não destrutivo de estimativa de área foliar a partir da nervura principal para cultivares de Vitis vinifera}

\begin{abstract}
Corresponding author: amanda-junges@agricultura. rs.gov.br

Received: April 19, 2021 Accepted: June 09, 2021

Copyright: All the contents of this journal, except where otherwise noted, is licensed under a Creative Commons Attribution License.
\end{abstract}

\section{(cc) $\mathbf{E Y}$}

Resumo - Modelos matemáticos são métodos indiretos de determinação da área foliar (AF) e parâmetro de quantificação do vigor em videiras destinadas à produção de vinhos finos. Objetivo deste trabalho foi ajustar e validar modelos matemáticos de estimativa de AF a partir da nervura principal para videiras conduzidas em sistemas horizontal e vertical, na Serra Gaúcha, Brasil. Foram coletadas folhas de 'Chardonnay' e 'Cabernet Sauvignon' em vinhedos conduzidos em latada e lira, e de 'Merlot' em latada e espaldeira. Foram testados modelos para relação entre AF e nervura principal, considerando as combinações de cultivar/sistema de condução e o conjunto de dados (geral). Para validação, foram definidas equações de regressão linear entre AF medida (planímetro eletrônico) e estimada. A relação entre comprimento da nervura principal e AF foi definida por equações não lineares do tipo potência $\left(\mathrm{R}_{\mathrm{aj}}^{2} 0,95-0,98\right)$. Modelo geral representou os demais, com desempenho semelhante aos específicos para cultivar/sistemas de condução. $\mathrm{Na}$ validação, todos os modelos apresentaram desempenho excelente (correlação 0,95-0,98; índice de Wilmott >0,97; índice de confiança >0,92). É possível estimar AF de videiras 'Chardonnay', 'Cabernet Sauvignon' e 'Merlot' por meio de modelo simples e não destrutivo, empregando uma única medida do limbo foliar, tornando mais fácil e rápida a caracterização do dossel vegetativo. Termos para indexação: 'Chardonnay', 'Cabernet Sauvignon', 'Merlot', Serra Gaúcha. 


\section{Introduction}

Leaf area is an important parameter for evaluating plant growth and development, determining photosynthetic activity, water absorption and evapotranspiration, as well as estimating injuries caused by pests or diseases (MONTERO et al. 2000; BUTTARO et al. 2015). In viticulture, the leaf area quantifies the vigor of the vegetative canopy, which is related to the quality and oenological potential of the grapes (DRISSI et al. 2009; BORGHEZAN et al. 2010). In the vine, as in most fruit species, the balance between the fruit load (drain) and the properly illuminated leaf area (source) influences the quantity and quality of production (SILVA et al. 2009). Thus, determining the leaf area is essential for microclimatic characterization and evaluation of plant response to edaphoclimatic conditions, management systems and practices. From the leaf area, important viticulture parameters can be obtained, such as leaf area index (LAI), leaf/fruit ratio, and illuminated leaf area/ shaded leaf area ratio (LOPES et al. 2005).

Despite the importance of the leaf area in vineyards, quantifying and monitoring this variable is not an easy and quick task. Direct methods to determine area are based on leaf blade measurements, which can be destructive or non-destructive. In the destructive methods, the leaves are removed from plants to determine measurements employing leaf area integrators (planimeters), scanners, or photographic cameras (BOSCO et al. 2012).

Generally, in addition to requiring equipment and time to collect and analyze the samples, this type of measurement cannot be repeated many times throughout the cycle due to the reduction of the photosynthetically active area. Non-destructive measurement methods can be more efficient because, besides not compromising the evaluation of other leaf area-dependent parameters, they reduce the variability associated with the sampling procedures (SILVA et al. 2004). Non-destructive direct methods consist of portable leaf area integrators, which allow measurements in the field and in real-time. Despite the practicality, these methods are little used by viticulturists because the equipment acquisition demands financial resources, in addition to calibrations, and standard measurement protocols.

Indirect methods for determining leaf area are based on establishing the relationship between leaf area and other plant-related parameters. For vines, several studies have proposed to estimate the area through leaf blade measurements, especially of the midvein and secondary veins (GUTIERREZ; LAVÍN, 2000; MONTERO et al., 2000; DEMIRSOY, 2009; BORGHEZAN et al., 2010; EFTEKHARI et al., 2011; BUTTARO et al., 2015). However, this indirect and non-destructive method requires first a mathematical model (equation) to define the relationship between the veins and the leaf area, which may vary according to the species, cultivar, rootstock, edaphoclimatic conditions, and vineyard management. Mathematical equations are generally considered accurate, easy to use while allowing for quick measurements in the field and successive evaluations throughout the cycle. Specific models are necessary for each plant species however morphological variability of leaves requires adjusting the equations for different cultivars as well (BORGHEZAN, et al. 2010).

In Brazil, to estimate leaf area in vineyards, Pedro Júnior et al. (1986) and Permanhani et al. (2014) established mathematical equations based on the width of the leaves of 'Niágara Rosada' cultivated, respectively, in São Paulo and Rio de Janeiro. In Paraná, Malagi et al. (2010) defined that, for the BRS-Violeta cultivar, the leaf area can be obtained by a quadratic equation using the sum of the length of the secondary veins. In Santa Catarina, Borghezan et al. (2010) established models to estimate the Vitis vinifera LA using the lengths of the midvein (for 'Merlot') and secondary veins (for 'Cabernet Sauvignon' and 'Sauvignon Blanc'). Amarante et al. (2009) defined that the midvein length provided a good estimate of the leaf area in young 'Cabernet Sauvignon' plants while including other leaf blade measurements resulted in an exceedingly small increase in the predictive capacity of the models.

In the state of Rio Grande do Sul, Cardoso (2007) estimated the leaf area of 'Moscato Giallo' from the sum of the length of secondary veins as proposed by Carbonneau (1976). Anzanello (2009) and Comiran (2009) calculated the leaf area index (LAI) of 'Niágara Branca', 'Niágara Rosada' and 'Concord' using a method adapted from Carbonneau (1976) that multiplies the length by the width of the leaves. Although important for defining area estimation parameters through leaf blade measurements, these works are specific to the growing conditions of the areas where they were developed. Furthermore, there are no studies defining leaf area estimation models for more than one cultivar while also considering any variations or adjustments necessary for the different canopy training systems of vineyards in the Serra Gaúcha region, the largest and most important wine-producing center in Brazil (PROTAS; CAMARGO, 2011).

In addition, although widely used in academia, models that employ more than one leaf blade measurement to estimate the area have little practical applicability for the viticultors, given the time and labor required to measure the midvein and secondary veins and, in some cases, the width of the leaf blade as well.

The objective of this work was to adjust and validate models for estimating the unit leaf area from the midvein for 'Cabernet Sauvignon', 'Chardonnay' and 'Merlot' vines conducted in horizontal and vertical training systems in the Serra Gaúcha region, RS, Brazil. 


\section{Material and Methods}

To adjust the unit leaf area models, leaves of 'Chardonnay', 'Cabernet Sauvignon' and 'Merlot' were collected in vineyards located on a family property in Veranópolis, in the Serra Gaúcha region, Rio Grande do Sul. According to the Köppen classification (ALVARES et al. 2013), the regional climate is Cfb type, a temperate climate (C) with no defined dry season (f) - no month with average rainfall less than $60 \mathrm{~mm}$, and mild summers (b) - the average temperature of the hottest month is below $22^{\circ} \mathrm{C}$. In Veranópolis, the $1956-2015$ (60 years) series records annual rainfall of $1,683 \mathrm{~mm}$, ranging between $109 \mathrm{~mm}$ (May) and $181 \mathrm{~mm}$ (September) (JUNGES et al. 2019). The average monthly air temperature is $17.3^{\circ} \mathrm{C}$, varying between $12.7^{\circ} \mathrm{C}$ (July) and $21.8^{\circ} \mathrm{C}$ (January) (JUNGES, 2018).

For adjusting and validating the leaf area estimation models, leaves were collected in vineyards with the following cultivar/training system combinations: 'Chardonnay' in trellis (CHLA) and lyre (CHLI); 'Cabernet Sauvignon' in trellis (CALA) and lyre (CALI), and 'Merlot' in trellis (MELA) and espalier (MEES) systems. Among the Vitis vinifera L. group, these cultivars cover the largest cultivated area in the Serra Gaúcha region, raking from the largest to the smallest, 'Chardonnay' (514 ha), 'Cabernet Sauvignon' (482 ha), and 'Merlot' (472 ha) (MELLO et al. 2017). These vineyards represent the productive system of grapes used for fine and sparkling wines produced in the Serra Gaúcha region. In the horizontal training system, which can be continuous (trellis) or discontinuous (lyre), the vegetative canopy is conducted horizontally and elevated, in wires at 1.8 meters from the ground. In the lyre system, the plants are conducted as sloping curtains with a "Y" shape, leaving an opening of the vegetative canopy between the rows. The spacing varies between 2 and 2.5 meters between rows and 1.5 and 2 meters between plants. In the espalier system, the vegetative canopy is conducted vertically, in double curtains, with the first wire placed at $1 \mathrm{~m}$ above the ground, the second and third at 1.30 and $1.80 \mathrm{~m}$, respectively, spacing of $2.75 \mathrm{~m}$ between rows and $1 \mathrm{~m}$ between plants. The vineyards are adjacent in a north-south direction.

A total of 450 leaves were collected for each cultivar/training system combination, of which 200 leaves in the 2013/2014 harvest and 250 leaves in the 2014/2015 harvest (Figure 1). The leaves with petiole were stored in paper bags and kept refrigerated to minimize deterioration between sampling and laboratory scanning, which was performed within 24 hours. In the laboratory, the petioles were removed, and the midvein length was determined using a graduated ruler (in millimeters) while the leaf area was determined using a LICOR leaf area meter (electronic planimeter) model 3100 .
Initially, descriptive statistics (mean, median, minimum and maximum) values were determined, and the midvein and leaf area data were checked for normality by the Kolmogorov-Smirnov (KS) test.

Linear and non-linear models were adjusted and tested to determine the best to describe the relationship between leaf area and midvein length for each cultivar/ training system combination $(n=350)$ and the data set (general model) $(n=2,100)$. The best models were chosen based on the highest value of the adjusted coefficient of determination $\left(\mathrm{R}_{\mathrm{aj}}^{2}\right)$, lowest standard error of the estimate $(\mathrm{SE})$, and model significance $(\mathrm{p}<0.05)$. The goodness of fit of the selected models was verified by the adjusted coefficient of determination $\left(\mathrm{R}_{\mathrm{aj}}^{2}\right)$ and the residual homoscedasticity test, considering the null hypothesis (H0) that the variance of the residuals is similar in all observations.

The ability of the general model to represent the others was evaluated by comparing the confidence intervals (CI 99\%) of the angular coefficients using the t-test $(\mathrm{p}<0.05)$.

To validate the adjusted models for each cultivar/ training system combination $(n=100)$, linear regression equations were defined between the observed and estimated leaf area considering both the cultivar/training specific model and the general model. The leaf area measured using electronic planimeter and those estimated by the models were then compared to evaluate the performance of each adjusted model. Performance was tested using the coefficient of correlation (r) for determining accuracy; Willmott index (d) for the agreement of the estimated variables (WILLMOTT, 1981); and confidence index (c) for evaluating the confidence or performance of the model (CAMARGO; SENTELHAS, 1997). All analyses were performed using the R software (CORE TEAM, 2018) 


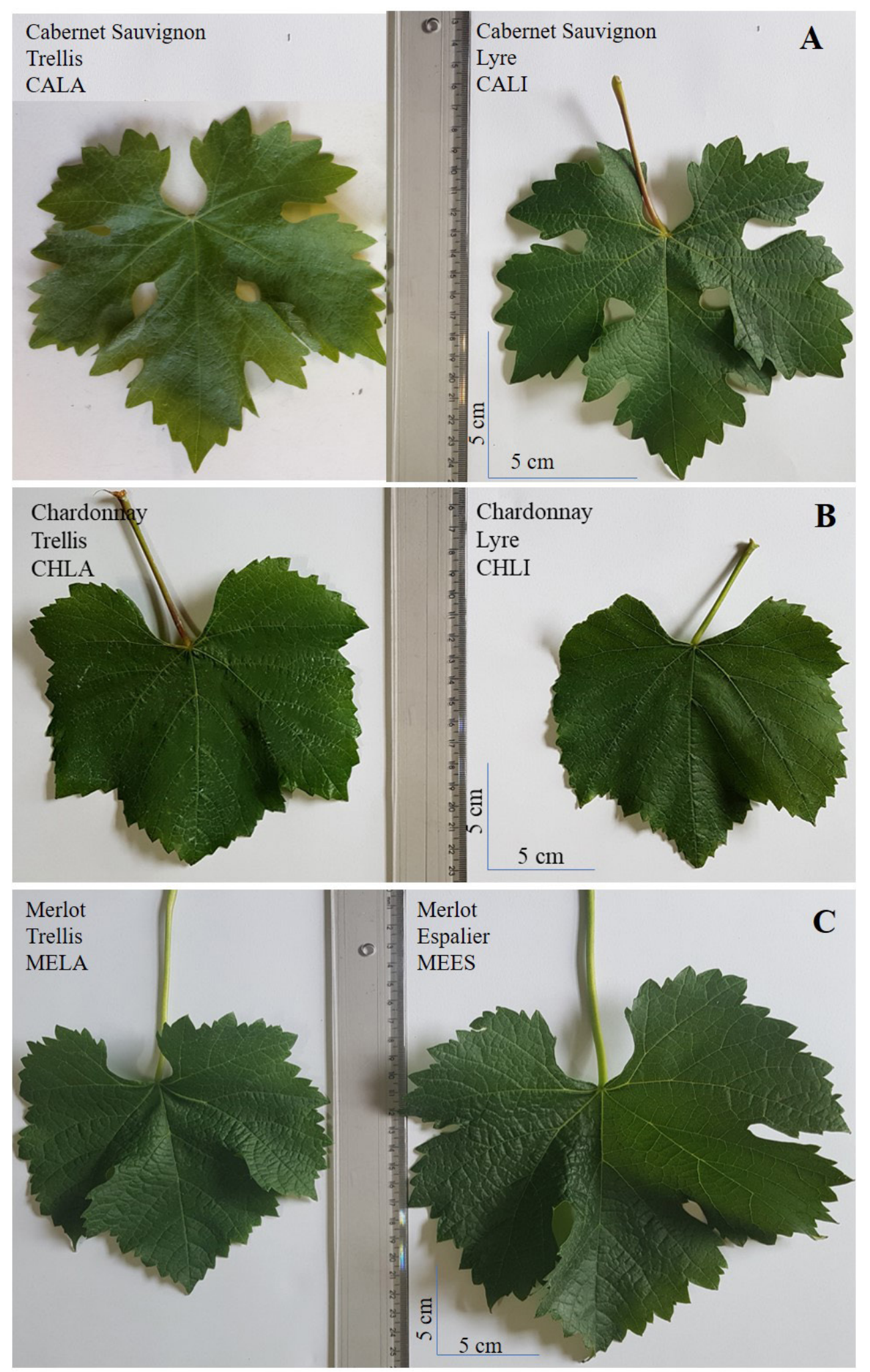

Figure 1. Leaf samples (Vitis vinifera) from (A) Cabernet Sauvignon (CA), (B) Chardonnay (CH), and (C) Merlot (ME) cultivars conducted in horizontal training systems (trellis - LA and lyre - LI) and vertical training system (espalier - ES) used to adjust and validate models for estimating leaf area $\left(\mathrm{cm}^{2}\right)$ based on the length of the midvein (cm), in Veranópolis, RS. 


\section{Results and discussion}

The results showed that, on average, the midvein length of the sampled leaves ranged between $8.5 \mathrm{~cm}$ (CALA) and $9.8 \mathrm{~cm}$ (CHLI) (Figure 2A) and the leaf area between $88 \mathrm{~cm}^{2}$ (CALA) and $128 \mathrm{~cm}^{2}$ (CHLI) (Figure 2B). In all treatments, leaves of different sizes were sampled, so that the midvein length and leaf area ranged from minimum values of $1 \mathrm{~cm}$ and $1.1 \mathrm{~cm}^{2}$ to maximum values of $16.5 \mathrm{~cm}$ and $299 \mathrm{~cm}^{2}$ (Figure 2), respectively. Leaves of different sizes must compose the samples used to adjust the leaf area estimation models to guarantee the reliability of the generated equation (DEMIRSOY, 2009). Furthermore, the variability of the sampled leaves is essential to ensure the representativeness of the conditions found in the field. The inclusion of smaller leaves is essential for adjusting models that can be used to determine the leaf area in the early stages of the vine vegetative cycle.

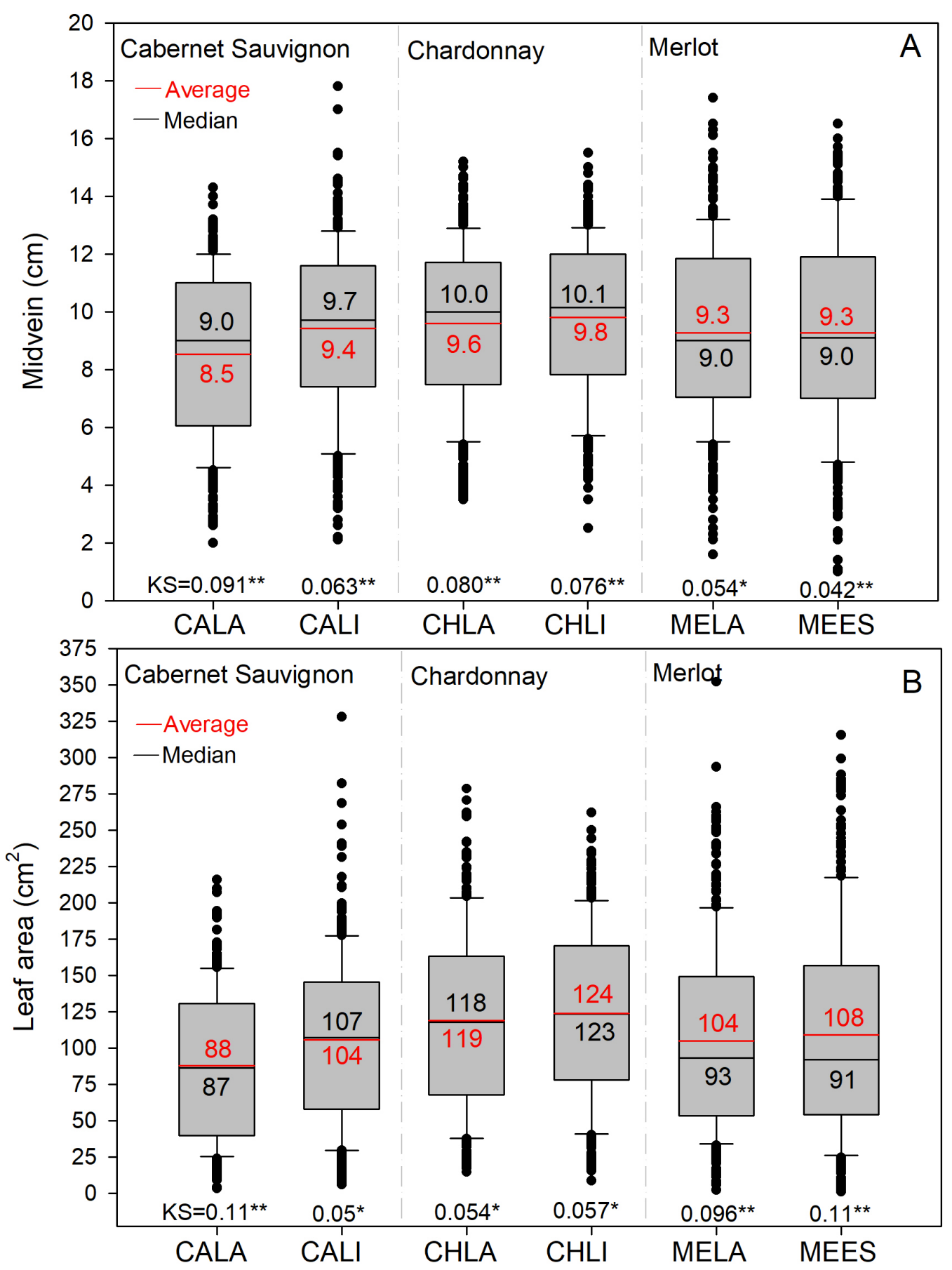

Figure 2. Data dispersion, average, median, value and significance $(* * p<0.01 ; * p<0.05)$ of the KolmogorovSmirnov (KS) normality test for (A) midvein length $(\mathrm{cm})$ and (B) observed leaf area $\left(\mathrm{cm}^{2}\right)$ of Vitis vinifera leaves from the Chardonnay $(\mathrm{CH})$, Cabernet Sauvignon $(\mathrm{CA})$ and Merlot $(\mathrm{ME})$ cultivars conducted in horizontal (trellis - LA and lyre - LI) and vertical (espalier - ES) training systems, in Veranópolis, RS. 
For vine leaves, the relationship between midvein length and leaf area was defined by non-linear powertype equations (Table 1) (Figure 3), with $\mathrm{R}_{\text {aj }}^{2}$ of 0.95 and 0.98 and SE between 0.13 and 0.15 , indicating a good fit of the models. The midvein length and leaf area data did not have a normal distribution (Figure 2), so the homoscedasticity of the residues was tested by the nonparametric Chi-Square statistic $\left(\chi^{2}\right)$ to determine whether there is a significant difference between observed and expected frequencies for a given event, based on the null hypothesis (VIALI, 2008).

Table 1. Estimation of parameters (adjusted coefficient of determination $-\mathrm{R}_{\mathrm{aj}}^{2}$; standard error of the estimate - SE; significance - $p$-value) of linear and non-linear equations (logarithmic, power, exponential and quadratic) between midvein length $(\mathrm{cm})$ and unit leaf area $\left(\mathrm{cm}^{2}\right)$ of Vitis vinifera leaves from the Chardonnay $(\mathrm{CH})$, Cabernet Sauvignon (CA) and Merlot (ME) cultivars conducted in horizontal training systems (trellis - LA and lyre - LI) and vertical training system (espalier - ES) and for the (general) dataset, in Veranópolis, RS.

\begin{tabular}{|c|c|c|c|c|c|c|}
\hline \multirow{2}{*}{$\begin{array}{c}\text { Treatment } \\
\text { (cultivar -training system) }\end{array}$} & \multirow[b]{2}{*}{ Parameter } & \multicolumn{5}{|c|}{ Model } \\
\hline & & Linear & Logarithmic & Power & Exponential & Quadratic \\
\hline \multirow{3}{*}{$\begin{array}{l}\text { Cabernet Sauvignon - } \\
\text { trellis (CALA) }\end{array}$} & $\mathrm{R}_{\mathrm{aj}}^{2}$ & 0.94 & 0.86 & 0.97 & 0.92 & 0.95 \\
\hline & $\mathrm{SE}$ & 12.81 & 18.92 & 0.14 & 0.21 & 11.29 \\
\hline & $p$-value & $<0.01$ & $<0.01$ & $<0.01$ & $<0.01$ & $<0.01$ \\
\hline \multirow{3}{*}{$\begin{array}{c}\text { Cabernet Sauvignon - } \\
\text { lyre (CALI) }\end{array}$} & $\mathrm{R}_{\mathrm{aj}}^{2}$ & 0.92 & 0.80 & 0.96 & 0.91 & 0.94 \\
\hline & $\mathrm{SE}$ & 16.43 & 25.45 & 0.14 & 0.21 & 13.48 \\
\hline & $p$-value & $<0.01$ & $<0.01$ & $<0.01$ & $<0.01$ & $<0.01$ \\
\hline \multirow{3}{*}{$\begin{array}{l}\text { Chardonnay - trellis } \\
\text { (CHLA) }\end{array}$} & $\mathrm{R}_{\mathrm{aj}}^{2}$ & 0.92 & 0.85 & 0.96 & 0.93 & 0.94 \\
\hline & $\mathrm{SE}$ & 17.23 & 23.74 & 0.13 & 0.17 & 15.15 \\
\hline & $p$-value & $<0.01$ & $<0.01$ & $<0.01$ & $<0.01$ & $<0.01$ \\
\hline \multirow{3}{*}{$\begin{array}{c}\text { Chardonnay - lyre } \\
\text { (CHLI) }\end{array}$} & $\mathrm{R}_{\mathrm{aj}}^{2}$ & 0.92 & 0.86 & 0.95 & 0.91 & 0.93 \\
\hline & $\mathrm{SE}$ & 15.83 & 21.54 & 0.13 & 0.18 & 14.94 \\
\hline & $p$-value & $<0.01$ & $<0.01$ & $<0.01$ & $<0.01$ & $<0.01$ \\
\hline \multirow{3}{*}{ Merlot -trellis (MELA) } & $\mathrm{R}_{\text {aj }}^{2}$ & 0.92 & 0.78 & 0.96 & 0.90 & 0.96 \\
\hline & $\mathrm{SE}$ & 16.92 & 29.53 & 0.15 & 0.24 & 12.42 \\
\hline & $p$-value & $<0.01$ & $<0.01$ & $<0.01$ & $<0.01$ & $<0.01$ \\
\hline \multirow{3}{*}{ Merlot - espalier (MEES) } & $\mathrm{R}_{\text {aj }}^{2}$ & 0.93 & 0.74 & 0.98 & 0.89 & 0.98 \\
\hline & $\mathrm{SE}$ & 19.01 & 36.26 & 0.13 & 0.30 & 12.12 \\
\hline & $p$-value & $<0.01$ & $<0.01$ & $<0.01$ & $<0.01$ & $<0.01$ \\
\hline \multirow{3}{*}{ General (all) } & $\mathrm{R}_{\mathrm{aj}}^{2}$ & 0.92 & 0.79 & 0.96 & 0.90 & 0.95 \\
\hline & $\mathrm{SE}$ & 17.96 & 28.47 & 0.15 & 0.23 & 14.23 \\
\hline & $p$-value & $<0.01$ & $<0.01$ & $<0.01$ & $<0.01$ & $<0.01$ \\
\hline
\end{tabular}



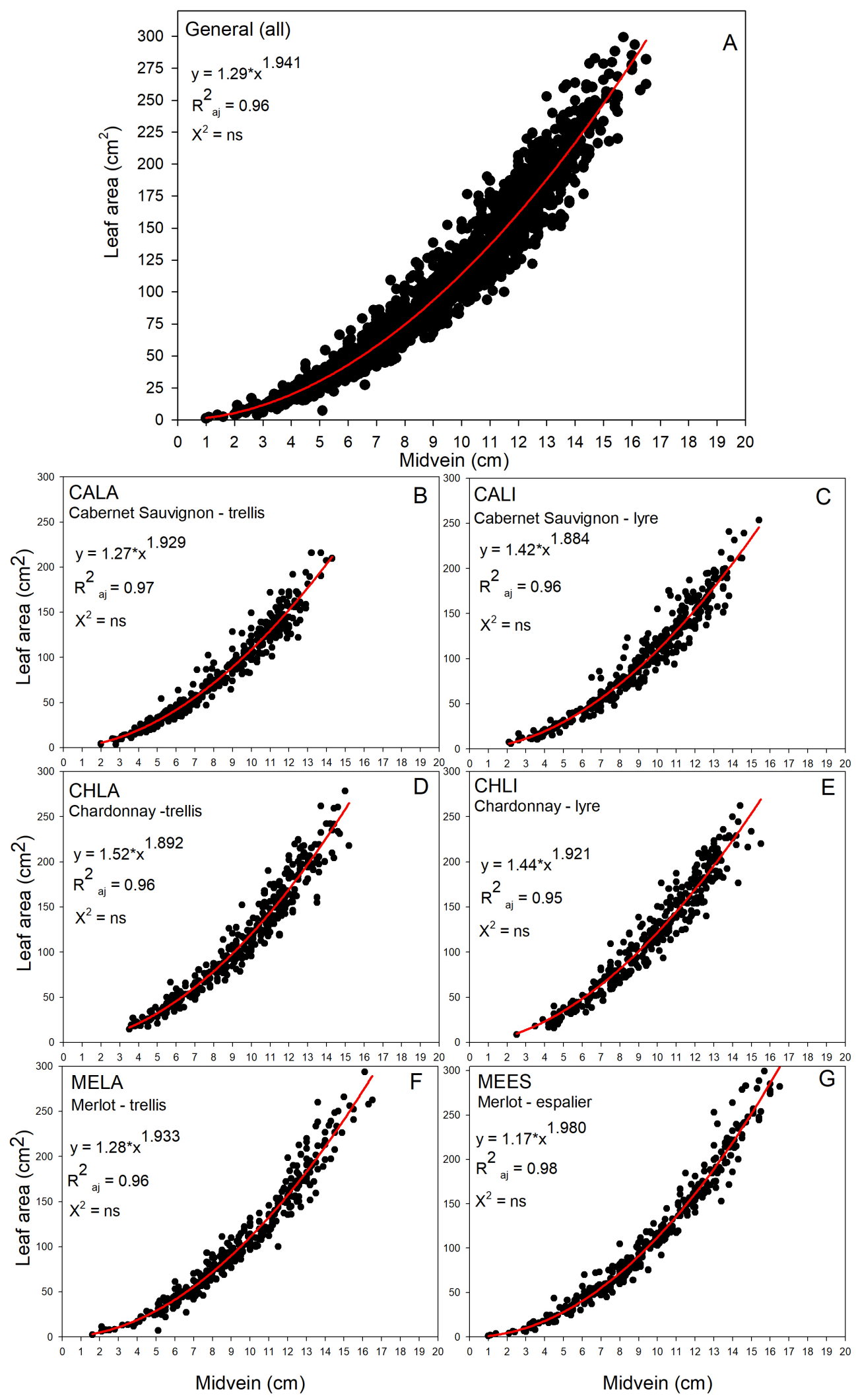

Figure 3. Potential equation, adjusted coefficient of determination $\left(\mathrm{R}_{\mathrm{aj}}^{2}\right)$ and residual homoscedasticity test $-\chi^{2}(\mathrm{~ns}=$ not significant) of models for estimating unit leaf area $\left(\mathrm{cm}^{2}\right)$ of Vitis vinifera leaves: general model (A) and model for Cabernet Sauvignon cultivar in trellis (CALA) (B) and lyre (CALI) (C); Chardonnay cultivar in trellis (CHLA) (D) and lyre (CHLI) (E); Merlot cultivar in trellis (MELA) (F) and espalier (MEES) (G), in Veranópolis, RS. 
The results indicated that the mathematical models for estimating the leaf area from the midvein length showed non-significant $\chi^{2}$ statistics (Figure 3 ), therefore, the residual variance was similar in all observations, indicating the values are homogeneous and confirming the good fit of the selected models.

Likewise, Borghezan et al. (2010) proposed potential models with higher coefficients of determination for estimating the leaf area of 'Cabernet Sauvignon' and 'Sauvignon Blanc'. Similarly, Permanhani et al. (2014) defined that the relationship between leaf width and leaf area of 'Niágara Rosada' vines is best adjusted by a potential model with a coefficient of determination of 0.96. However, Amarante et al. (2009) and Gutierrez and Lavín (2000) proposed linear models for estimating the leaf area of 'Cabernet Sauvignon' and 'Chardonnay', respectively, whereas Borghezan et al. (2010) concluded that a polynomial equation best estimated the 'Merlot' leaf area.

Potential equations adequately expressed the relationship between the midvein length and unit area of 'Merlot', 'Cabernet Sauvignon' and 'Chardonnay' leaves, and can be used in estimation models. Campostrini and Yamanish (2001) also used only the midvein length in a logarithmic model $\left(\mathrm{R}^{2}=0.90\right)$ to estimate the leaf area of papaya. The results of our work demonstrated that it is possible to develop a non-destructive mathematical model to estimate leaf area from a single measurement. Models requiring the length measurement of only one vein of Vitis vinifera are preferable to other models, due to the practicality and speed to collect data in the field (MONTERO et al. 2000; BORGHEZAN et al. 2010; BUTTARO et al. 2015). Also important for model applicability, the midvein is easily identified and measured, compared to other leaf blade parameters, such as, for example, the secondary veins and the length between tips of lateral lobes. Furthermore, the selection of a model requires balancing the predictive qualities of the model while including a minimum number of variables needed to estimate leaf area (BUTTARO et al. 2015).

The confidence intervals of the angular coefficients obtained for the adjusted models for each cultivar/ training system compared to the general model were not significantly different (Figure 4). Therefore, it is concluded that the management systems did not promote significant differences in the leaf area estimated models of the evaluated cultivars so that the general model is considered representative and can be used to estimate the leaf area of the Cabernet Sauvignon, Merlot and Chardonnay cultivars. This result is important since a single equation (general model) allows to determine leaf area estimates, regardless of cultivar or training system evaluated in this work. Similarly, Campostrini and Yamanish (2001) proposed a unique mathematical model to estimate the leaf area of four papaya genotypes whereas Bosco et al. (2012) proposed models for estimating leaf area of 'Royal Gala' and 'Fuji Suprema' apple cultivars, without distinction between growing conditions (under an anti-hail net and open sky). For Vitis vinifera, Eftekhari et al. (2011) defined mathematical models for estimating leaf area without distinguishing among Iranian vine 'Asgari', 'Keshmeshi', 'Shahroodi' and 'Khalili'. Likewise, Buttaro et al. (2015) found no differences between the mathematical models for estimating the leaf area of 'Big Perlon', 'Black Magic', 'Crimson', 'Michele Palieri', 'Red Globe', 'Sugraone', 'Victoria' and 'Vitroblack' and developed a unique regression model for the evaluated vine cultivars.

In this work, the general model represents the others (Figure 4), with a performance similar to the specific models for each cultivar/training system combination (Figure 5). The regression line between observed and estimated values using the general model was close to the 1:1 ratio in all evaluated treatments (Figure 5), with accuracy and confidence index values similar to those obtained by the specific models for each cultivar/training system. It is highlighted that all evaluated models had excellent performance, with correlation values between observed data and estimated data ranging from 0.95 (Figure 5A) to 0.98 (Figure 5E and 5F), Wilmott indexes (d) greater than 0.97 and confidence (c) above 0.92 (Figure 5). The $d$ index, which assesses the degree to which the model simulations are free of error, represents the model accuracy and varied between 0 (no agreement) and 1 (perfect agreement). Confidence indices above 0.85 indicate excellent performance according to the criterion for interpreting the performance of estimation methods proposed by Camargo and Sentelhas (1997), also used in the performance evaluation of leaf area estimation models by Bosco et al. (2012) and Dalmago et al. (2017).

Although Vitis vinifera cultivars have truly diverse leaf morphology, which allows recognizing the varietal groups in ampelographic studies, the mathematical equations defined for determining the leaf area of a given cultivar can be used to estimate the leaf area of others, as demonstrated by the results of this work. However, studies that require high precision results, or to estimate the leaf area of vine cultivars with different morphology, such as Vitis labrusca and hybrids, for example, it may be necessary to adopt specific models, depending on the variability of leaves or eventual morphological and physiological characteristics. 
The search for a simple and easy way to determine the leaf area of Vitis vinifera vines, which have a complex morphology, is essential for assessments that require measuring the leaf area of the vegetative canopy. Thus, the fitting and validating of a single model for the studied cultivars and different training systems, as an indirect and non-destructive method that does not require special equipment but only a single measurement of the leaf blade, can optimize the characterization and quantification of the vegetative canopy in wine grape production systems.
The model can be considered valid for leaves with characteristics similar to those of the evaluated cultivars (Cabernet Sauvignon, Merlot, and Chardonnay), and can be used both in academia and by viticulturists, given that the requirement of a single measurement of the leaf blade makes the model easy and quick to implement. The midvein length can be measured in the field using a ruler or even through digital images, whose potential use for estimating the leaf area in canola and apple trees was demonstrated by Bosco et al. (2012) and Dalmago et al. (2017).

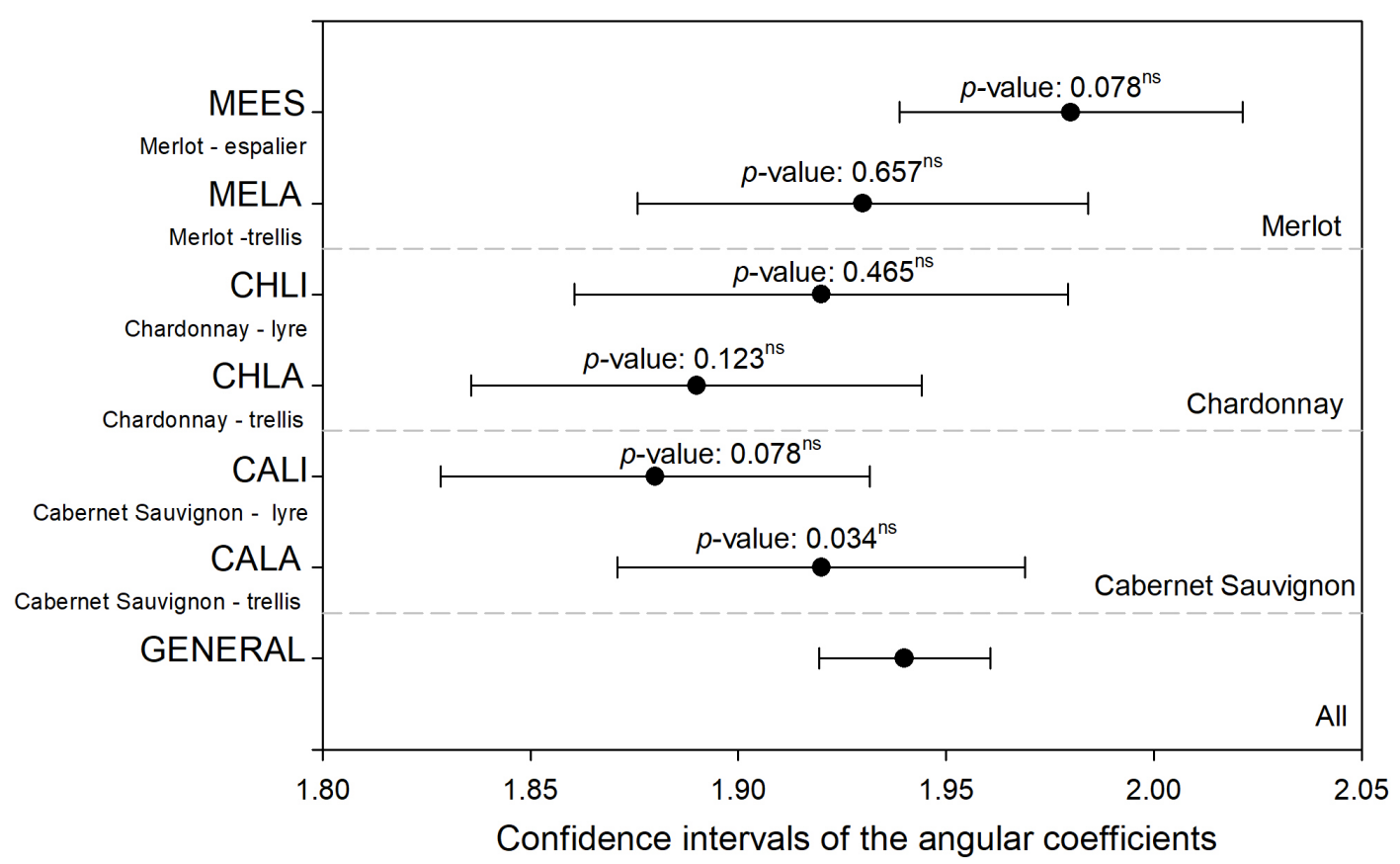

Figure 4. Confidence intervals of the angular coefficients and significance (ns = non-significant) of the t-test for comparing the general model and specific models to cultivar/training system combination to estimate the Vitis vinifera leaf area $\left(\mathrm{cm}^{2}\right)$ from the midvein length $(\mathrm{cm})$ in Chardonnay $(\mathrm{CH})$, Cabernet Sauvignon $(\mathrm{CA})$ and Merlot $(\mathrm{ME})$ cultivars conducted in horizontal (trellis - LA and lyre - LI) and vertical (espalier - ES) training systems, in Veranópolis-RS. 

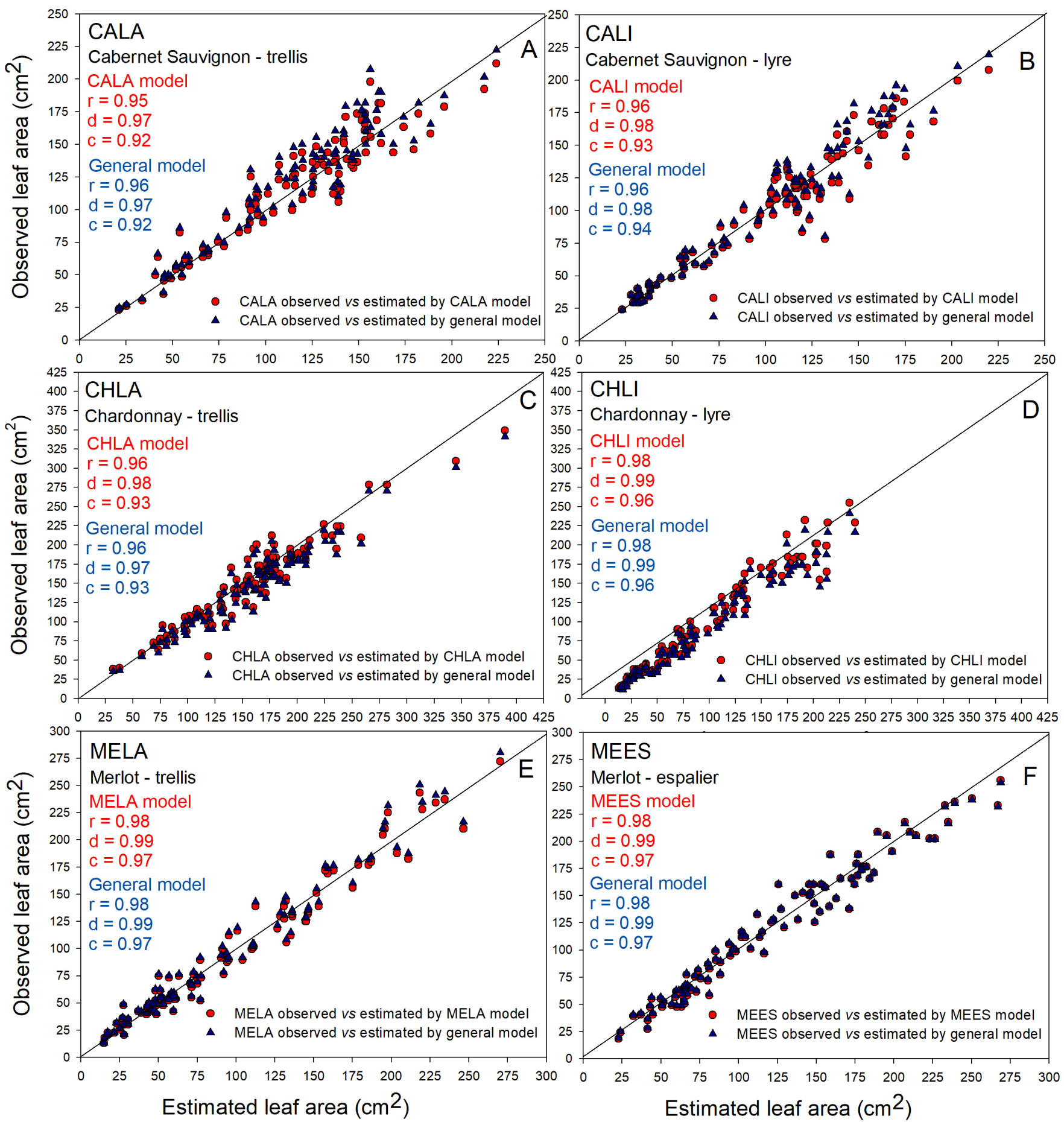

Figure 5. Association between observed and estimated values and performance parameters (correlation coefficient - r; Willmott index - d; confidence index - c) for validating leaf area estimation models $\left(\mathrm{cm}^{2}\right)$ using the Vitis vinifera midvein length (cm): general model and specific model for each cultivar/training system combination: Cabernet Sauvignon in trellis (CALA) (A); Cabernet Sauvignon in lyre (CALI) (B); Chardonnay in trellis (CHLA) (C); Chardonnay in lyre (CHLI) (D); Merlot in trellis (MELA) (E); and Merlot in espalier (MEES) (F), in Veranópolis, RS. 


\section{Conclusion}

In 'Chardonnay', 'Cabernet Sauvignon' and 'Merlot' vines, the leaf area can be estimated in a nondestructive way by potential equations using the midvein length as an independent variable.

Thus, the vine leaf area can be estimated by a unique mathematical model regardless of cultivars ('Chardonnay', 'Cabernet Sauvignon' and 'Merlot') and canopy training systems (horizontal and vertical).

A single general mathematical model $(\mathrm{y}=$ $\left.1.29 * \mathrm{x}^{1.941}\right)$ based on a single measurement of the leaf blade (midvein lenght) can be used to obtain the leaf area of 'Chardonnay', 'Cabernet Sauvignon' and 'Merlot' vines in the growing conditions of the Serra Gaucha region

\section{References}

ALVARES, C.A.; STAPE, J.L.; SENTELHAS, P.C.; GONÇALVES, J.L.M.; SPAROVEK, G. Köppen's climate classification map for Brazil. Meteorologische Zeitschrift, Stuttgart, v.22, n.6, p.711-728, 2013.

AMARANTE, C.V.T.; ZANARDI, O.Z.; MIQUELOTO, A.; STEFFENS, C.A.; ERHART, J.; ALMEIDA, J.A. Quantificação da área e do teor de clorofila em folhas de plantas jovens de videira 'Cabernet Sauvignon' mediante métodos não destrutivos. Revista Brasileira de Fruticultura, Jaboticabal, v.31, n.3, p.680-686, 2009.

ANZANELLO, R.Comportamento produtivo e fisiológico de três cultivares de videira submetidas a duas safras por ciclo vegetativo pelo manejo da poda. 2009. Dissertação (Mestrado em Fruticultura) - Faculdade de Agronomia, Universidade Federal do Rio Grande do Sul, Porto Alegre, 2009.

BORGHEZAN, M.; GAVIOLI, O.; PIT, F.A.; SILVA, A.L. Modelos matemáticos para a estimativa da área foliar de variedades de videira a campo (Vitis vinifera L.). Ciência e Técnica Vitivinícola, Runa, v.25, n.1, p.1-7, 2010.

BOSCO, L.C., BERGAMASCHI, H., CARDOSO, L.S., DE PAULA, V.A., CASAMALI, B. Seleção de modelos de regressão para estimar a área foliar de macieiras 'Royal Gala' e 'Fuji Suprema' sob tela antigranizo e em céu aberto. Revista Brasileira de Fruticultura, Jaboticabal, v.34, n.2, p.504-514, 2012.
BUTTARO, D.; ROUPHAEL, Y.; RIVERA, C.M.; COLLA, G.; GONNELLA, M. Simple and accurate allometric model for leaf area estimation in Vitis vinifera L.genotypes. Photosynthetica, Praga, v.53, n.3, p.342$348,2015$.

CAMARGO, A.P.; SENTELHAS, P.C. Avaliação do desempenho de diferentes métodos de estimativa da evapotranspiração potencial no Estado de São Paulo. Revista Brasileira de Agrometeorologia, Santa Maria, v.5, n.1, p.89-97, 1997.

CAMPOSTRINI, E.; YAMANISHI, O.K. Estimation of papaya leaf area using the central vein length. Scientia Agricola, São Paulo, v.58, n.1, p.39-42, 2001.

CARBONNEAU, A. Analyse de la croissance des feuilles du sarment de vigne: estimation de la surface foliare par enchantillonnage. Connaissance Vigne Vin, Bordeaux, v.10, n.2, p.141-159, 1976.

CARDOSO, L.S. Alterações microclimáticas em vinhedos de Vitis vinífera L.cv.Moscato Giallo pelo uso de cobertura plástica. 2007. Dissertação (Mestrado em Agrometeorologia) - Faculdade de Agronomia, Universidade Federal do Rio Grande do Sul, Porto Alegre, 2007.

COMIRAN, F. Microclima, desenvolvimento e produção de videiras 'Niágara Rosada' em cultivo orgânico sob cobertura plástica. 2009. Dissertação (Mestrado em Agrometeorologia) - Faculdade de Agronomia, Universidade Federal do Rio Grande do Sul, Porto Alegre, 2009.

CORE TEAM. R: a language and environment for statistical computing. Viena: R Foundation for Statistical Computing, 2018. Disponível em: https://www.R-project. org/. Acesso em: 10 abr.2021.

DALMAGO, G.A.; GOUVÊA, J.A.; CUNHA, G.R.; VICARI, M.B.; KOVALESKI, S. Uso de imagens digitais para estimativa da área foliar da canola. In: SIMPÓSIO BRASILEIRO DE CANOLA, 1., 2017, Passo Fundo. Anais [...]. Brasília, DF: Embrapa, 2017. Disponível em: https://www.embrapa.br/busca-de-publicacoes/-/ publicacao/1084130/uso-de-imagens-digitais-paraestimativa-da-area-foliar-da-canola. Acesso em: 10 abr. 2021. 
DEMIRSOY, H. Leaf area estimation in some species of fruit tree by using models as a non-destructive method. Fruits, Cambridge, v.64, n.1, p.45-51, 2009.

DRISSI, R.; GOUTOULY, J.P.; FORGET, D.; GAUDILLERE, J.P. Nondestructive measurement of grapevine leaf area by ground normalized difference vegetation index. Agronomy Journal, Madison, v.101, n.1, p.226-231, 2009.

EFTEKHARI, M.; KAMKAR, B.; ALIZADEH, M. Prediction of leaf area in some Iranian table grape (Vitis vinifera L.) cuttings by a non-destructive and simple method.S cience Research Reporter, Jalna, v.1, n.3, p.115-121, 2011.

GUTIERREZ, A.T.; LAVÍN, A.A. Mediciones lineales en la hoja para la estimación no destructiva del área foliar en vides cv.Chardonnay. Agricultura Técnica, Chillán, v.60, n.1, p.69-73, 2000.

JUNGES, A.H. Caracterização climática da temperatura do ar em Veranópolis, Rio Grande do Sul. Agrometeoros, Passo Fundo, v.26, n.2, p.299-306, 2018.

JUNGES, A.H.; BREMM, C.; FONTANA, D.C. Rainfall climatology, variability, and trends in Veranópolis, Rio Grande do Sul, Brazil. Revista Brasileira de Engenharia Agrícola e Ambiental, Campina Grande, v.23, n.3, p.160-166, 2019.

LOPES, C.; PINTO, P.A. Easy and accurate estimation of grapevine leaf area with simple mathematical models. Vitis, Quedlinburg, v.44, n.2, p.55-61, 2005.

MALAGI, G.; CITADIN, I.; SCARIOT, S.; REIS, L. Método não destrutivo para determinação da área foliar da videira, cultivar BRS-Violeta. Revista Brasileira de Fruticultura, Jaboticabal, v.32, n.4, p.1250-1254, 2010.

MELLO, L.M.R; MACHADO, C.A.E.; SILVA, S.M.R., ZANESCO, R. Dados cadastrais da viticultura do Rio Grande do Sul: 2013 a 2015. Brasília: Embrapa, 2017. 85 p. Disponível em: http://www.alice.cnptia.embrapa.br/ alice/handle/doc/1084011. Acesso em: 01 abr. 2021.
MONTERO, F.J.; DE JUAN J.A.; CUESTAA.; BRASA A. Nondestructive methods to estimate leaf area in Vitis vinifera L. HortScience, Hanover, v.35, n.4, p.696-698, 2000.

PEDRO JÚNIOR, M.J.; RIBEIRO, I.J.A.; MARTINS, F.P. Determinação da área foliar em videira cultivar Niagara Rosada. Bragantia, Campinas, v.45, n.1, p.199-204, 1986.

PERMANHANI, M.; VASCONCELLOS, M.A.S.; SOUZA, R.T.; MARTELLETO, L.A.P. Estimativa de área foliar da videira 'Niágara rosada' conduzida em sistema de latada, região Norte Fluminense. Revista Brasileira de Fruticultura, Jaboticabal, v.36, n.4, p.1034-1040, 2014.

PROTAS, J.F.S.; CAMARGO, U.A. Vitivinicultura brasileira: panorama setorial de 2010. Brasília: SEBRAE, Bento Gonçalves: IBRAVIN, 2011. 110p.

SILVA, P.S.L; BARBIN, D.; GONÇALVES, R.J.S.; FIRMINO, J.D.C.; FONSECA, I.C. Leaf area estimates of custard apple tree progenies. Revista Brasileira de Fruticultura, Jaboticabal, v.26, n.3, p.558-560, 2004.

SILVA, L.C., RUFATO, L., KRETZSCHMAR, A.A., MARCON FILHO, J.L. Raleio de cachos em vinhedos de altitude e qualidade do vinho da cultivar Syrah. Pesquisa Agropecuária Brasileira, Brasília, DF, v.44, n.2, p.148154, 2009.

VIALI, L. Testes de hipóteses não paramétricos. Porto Alegre: UFRGS, 2008. 43 p. Disponível em: http://www. mat.ufrgs.br/ viali/estatistica/mat2282/material/apostilas/ Testes_Nao_Parametricos.pdf. Acesso em: 05 abr.2021.

WILLMOTT, C.J. On the validation of models. Physical Geography, Columbia, v.2, n.2, p.184- 194, 1981. 